\title{
Factors AfFecting Customers' Buying Decisions of Mobile Phone: A Study on KHULNA City, BANGLADESH
}

\author{
Md Reaz Uddin ${ }^{1}$ Nusrat Zahan Lopa ${ }^{2}$ and Md. Oheduzzaman ${ }^{3}$ \\ ${ }^{1}$ Assistant Professor, Business Administration Discipline, Khulna University, \\ Bangladesh \\ ${ }^{2}$ Assistant Professor, Business Administration Discipline, Khulna University, \\ Bangladesh \\ ${ }^{3}$ Independent Researcher, Khulna
}

\begin{abstract}
Mobile phone has diverse usages to different users in accordance with their necessities. With dramatic increase in mobile phone usage in recent years, people take into account various factors while they decide purchasing a mobile phone. This study has put efforts to uncover the underlying factors those affect customers in choosing mobile phone. Data were collected from those people live in Khulna city maintaining equal ratios of various groups like male, female, businessmen, employees, students and others (mostly housewives). To select desired respondents, convenient sampling method was used. A structured questionnaire designed based on previous study with five point Likert scale was used to interview respondents. Factor analysis was applied to extract the underlying factors affect mobile phone purchasing decision. The results show that the most important factor is physical attributes. Some other factors are pricing, charging and operating facilities, size and weight, friends' and colleagues' recommendations, neighbors' recommendations and advertising.
\end{abstract}

Key words: Mobile Phone, Purchasing Decisions, Customer Choice

\section{INTRODUCTION}

Communication is one of the most talked topics in today's business world. Among the different modes of communication, mobile phone is becoming reliable and efficient vehicle to reach from one person to another. This is the prevailing device through which we can now express ourselves, get our work done and share our joys and hurts. This picture was not seen almost two decades back when most of the people of this country were solely dependent on BTTB (Bangladesh telegraph and telephone board).

It was early nineties, the mobile phone handset first launched in Bangladesh with a very small number of penetration rate. At that time very few people were able to afford mobile phone as they faced different sorts of barriers. In 1997, Nokia started its operation in this country and presently operating a number of selling points in Bangladesh. Siemens and Samsung started their operation after launching it.

In this modern era, a wide variety of other services such as email, text messaging, MMS, internet access, audio and video, short range wireless communications (Inferred, Bluetooth), gaming etc. are also supported by the mobile phones. In addition to these, it also offers more general computing capabilities that are referred to smart phone. In Bangladesh many mobile phone brands are available e.g. Nokia, Samsung, Sony, HTC, Panasonic, Motorola, LG, Symphony, Micromax, Walton etc. and consumer choose their preferred mobile phone from this pool. 
This study has been designed with intention to identify the factors affect customers to choose their mobile phone. It focuses on probable reason that the customers consider to make their purchase decision regarding mobile phone.

\section{LITERATURE REVIEW}

There are many social and interpersonal factors that influence customers to decide about any product and so happen in mobile phone also. Consumer behavior is affected by a lots of variables, ranging from personal motivations, needs, attitudes and values, personality characteristics, socio-economic and cultural background, age, sex, professional status to social influences of various kinds exerted by family, friends, colleagues and society as a whole (Moschis, 1976).

Liu (2002) in a recent paper analyzed factors affecting the decision regarding brand in the mobile phone industry in Asia. It was found that the choice of a mobile phone is characterized by two distinct attitudes towards brands: attitudes towards the mobile phone brand and attitudes towards the network. Customers' choice of mobile phone brand is affected largely by new features more than size. This trend of choosing is definitely towards phones with better capacity and larger screens.

According to a latest report given by In-Stat/MDR (2002) research institute, color displays are now driving consumers into stores to purchase new mobile phones and related devices such as PDAs (personal digital assistants). The result that customers' choice criteria depends more importantly on color display than higher data rates or new features though the fact that the review of other studies had not cited the importance of color display. The report also indicates that the customers demand for color display handsets is increasing and it is expected that in this $21^{\text {st }}$ century all cellular phones and PDAs are equipped with color display.

Dorsch, Grove and Darden (2002) in their research on customer choice of mobile phone found that from the perspective of marketing consumer's purchase process can be classified into a five step problem solving process such as: need recognition, information search, given alternatives evaluation, purchase activity and post purchase evaluation. This five step process of decision making is most appropriate for the problem solving behavior of purchase making decision or complex decision purchase process. Similarly purchase decision for mobile handset pursues the same buying process but in some cases the decision may also be influenced by symbolic preference associated with some brands.

Before purchasing mobile phone consumers take some general conditions into consideration. Considering the classical problem solving buying process behavior, it is almost always a case that consumers go for information search before taking purchase decision. There is also a common behavior that consumer's decision of purchasing is directed by previous likings for some specific alternatives. It shows that customers formulate their purchasing decision based on the limited information search activity that they performed (Moorthy, Ratchfordand, Talukdar, 1997) rather than a detailed evaluation of all possible alternatives (Chernev, 2003).

Besides information search evaluation of alternatives is an important activity that determines consumer's choice (Laroche, Kim and Matsui, 2003). They opined that customer's purchase decision is influenced by 'cognitive heuristics' or in simple words a consumer choose his perceived brand based on his past experience if it fulfills his perceived values.

Swait and Adamowicz(2001) found that a lot of decision behavior exercised by purchasers can be different from one individual to another because customers may use different approaches to make their choices rather only using mathematical modeling.

A prospective buyer's decision of buying a product or brand may be influenced by personal preferences and perspective of buying may have a greater effect on brand choice if the customer 
has little subsequent knowledge or experience about the product. The conventional problem solving technique that is used in making purchasing decision that affects buyers' preference might not be the best approach in all conditions. Mobile phone selection can either be based on functional/primary/rational factors or it can be based on emotional factors such as: fun, pleasure, excitement etc. (Batra and Ahtola, 1990).

A lot of consumer's choice may be having both rational features (e.g communication, time management) as well as emotional features (e.g games, music, camera, and application). The younger the consumer the more he would prefer emotional rather than rational features in mobile phones (Wilska, 2003). Customers' decisions of purchasing mobile phone depend on rational as well as emotional factors.

Requelme (2001) conducted an experiment to identify the quantity of self-knowledge consumers have when choosing between mobile phone brands. The study was built upon six key attributes (telephone features, access cost, connection fee, mobile to mobile phone rates, call rates and free calls) related to mobile phone purchasing respondents had to importance rate.

\section{METHODOLOGY}

This study was conducted to know the factors affect people decisions of mobile phone purchasing. Primary and secondary data were collected from appropriate sources for collecting data. A structured questionnaire with five point likert scale was used to collect the opinions of respondents. To select the respondents, convenience sampling method was used. A total of 200 respondents were interviewed from them 160 were found flawless thus used for data analysis. Factor analysis and descriptive statistical tools were applied with SPSS for data analysis.

\section{ANALYSIS AND FINDING}

The data presented in the above table indicate that the sample is equal with both male and female respondents as they are indicated by 50 percent for both. Age analysis of respondents indicates that most of the respondents fall in the age group of 19-25 years as it was indicated by 21.2 percent respondents in the sample. Occupation shows that in case of service and students the respondents are 45 that indicate 28.1 percent for both and Business and Housewives include 35 respondents each that indicate 21.9 percent. In case of income level the most respondents fall under the income level of above 20000 that shows 30.6 percent.

Table 1: Demographic characteristic of respondents

\begin{tabular}{|c|l|c|c|}
\hline & \multicolumn{1}{|c|}{ Categories } & Count & Percentage \\
\hline Gender & Male & 80 & 50 \\
& Female & 80 & 50 \\
\hline \multirow{5}{*}{ Age group } & Below 18 & 14 & 8.8 \\
& $19-25$ & 34 & 21.2 \\
& $26-30$ & 31 & 19.4 \\
& $31-35$ & 29 & 18.1 \\
& $36-40$ & 22 & 13.8 \\
& Above 40 & 30 & 18.8 \\
\hline \multirow{3}{*}{ Occupation } & Service & 45 & 28.1 \\
& Students & 45 & 28.1 \\
& Business & 35 & 21.9 \\
& Housewives/Others & 35 & 21.9 \\
\hline
\end{tabular}


International Journal of Managing Value and Supply Chains (IJMVSC) Vol.5, No. 2, June 2014

\begin{tabular}{|l|l|l|l|}
\hline & Below 5000 & 40 & 25.0 \\
Income Level & 6000 to 10000 & 26 & 26.2 \\
& 11000 to 15000 & 23 & 14.4 \\
& 16000 to 20000 & 22 & 13.8 \\
& Above 20000 & 49 & 30.6 \\
\hline
\end{tabular}

\section{FACTOR ANALYSIS}

Table 2 - KMO and Bartlett's Test

\begin{tabular}{|c|c|c|}
\hline \multicolumn{2}{|c|}{$\begin{array}{l}\text { Kaiser-Meyer-Olkin Measure of Sampling } \\
\text { Adequacy. }\end{array}$} & .877 \\
\hline \multirow{3}{*}{$\begin{array}{l}\text { Bartlett's Test of } \\
\text { Sphericity }\end{array}$} & Approx. Chi-Square & 2.875 \\
\hline & $\mathrm{df}$ & \\
\hline & Sig. & .000 \\
\hline
\end{tabular}

The result obtained from 160 respondents had been thoroughly analyzed and the outputs of the results had been clearly explained in this section. To analyze the strength of association among variables the Kaiser-Mayer-Olkin (KMO) measure of sampling adequacy was applied. The KMO measure of sampling adequacy was computed to determine the suitability of using factor analysis. It certifies whether data are suitable to perform factor analysis. The value of KMO varies from 0 to 1 and high values (close to 1.0) generally indicate that a factor analysis may be useful with the data. KMO score should be 0.60 to be adequate for testing. KMO score .877 indicates adequacy for testing.

\section{Table 3 -Total Variance Explained}

\begin{tabular}{|c|c|c|c|c|c|c|c|c|c|}
\hline \multirow[b]{2}{*}{$\begin{array}{l}\text { Comp- } \\
\text { onent }\end{array}$} & \multicolumn{3}{|c|}{ Initial Eigenvalues } & \multicolumn{3}{|c|}{$\begin{array}{c}\text { Extraction Sums of Squared } \\
\text { Loadings }\end{array}$} & \multicolumn{3}{|c|}{$\begin{array}{l}\text { Rotation Sums of Squared } \\
\text { Loadings }\end{array}$} \\
\hline & Total & $\begin{array}{c}\% \text { of } \\
\text { Variance }\end{array}$ & $\begin{array}{c}\text { Cumulative } \\
\%\end{array}$ & Total & $\begin{array}{c}\% \text { of } \\
\text { Variance }\end{array}$ & $\begin{array}{c}\text { Cumulative } \\
\%\end{array}$ & Total & $\begin{array}{c}\% \text { of } \\
\text { Variance }\end{array}$ & $\begin{array}{c}\text { Cumulative } \\
\% \\
\end{array}$ \\
\hline 1 & 9.917 & 30.992 & 30.992 & 9.917 & 30.992 & 30.992 & 7.515 & 23.483 & 23.483 \\
\hline 2 & 3.356 & 10.487 & 41.479 & 3.356 & 10.487 & 41.479 & 4.650 & 14.530 & 38.013 \\
\hline 3 & 2.120 & 6.624 & 48.103 & 2.120 & 6.624 & 48.103 & 2.133 & 6.665 & 44.679 \\
\hline 4 & 1.890 & 5.906 & 54.009 & 1.890 & 5.906 & 54.009 & 2.124 & 6.636 & 51.315 \\
\hline 5 & 1.409 & 4.403 & 58.412 & 1.409 & 4.403 & 58.412 & 1.654 & 5.167 & 56.482 \\
\hline 6 & 1.284 & 4.014 & 62.426 & 1.284 & 4.014 & 62.426 & 1.624 & 5.076 & 61.558 \\
\hline 7 & 1.103 & 3.448 & 65.874 & 1.103 & 3.448 & 65.874 & 1.381 & 4.315 & 65.874 \\
\hline
\end{tabular}

Extraction method: Principal component analysis

Applying SPSS, the principal component analysis (PCA) was carried out to explore the underlying factors associated with 32 items. The above table shows that $65.87 \%$ of variation in mobile purchasing by the customers is explained by seven factors. 
International Journal of Managing Value and Supply Chains (IJMVSC) Vol.5, No. 2, June 2014

\begin{tabular}{|c|c|c|c|c|c|c|c|}
\hline & \multicolumn{7}{|c|}{ Component } \\
\hline & 1 & 2 & 3 & 4 & 5 & 6 & 7 \\
\hline Camera and video & .827 & & & & & & \\
\hline Bluetooth & .802 & & & & & & \\
\hline Multimedia option & .800 & & & & & & \\
\hline Touch Screen & .775 & & & & & & \\
\hline Memory capacity & .772 & & & & & & \\
\hline Color display & .763 & & & & & & \\
\hline Attractive color & .753 & & & & & & \\
\hline Model/style & .684 & & & & & & \\
\hline New features & .684 & & & & & & \\
\hline Design of the phone & .669 & & & & & & \\
\hline Appearance & .608 & & & & & & \\
\hline Web browser & .597 & & & & & & \\
\hline Brand value/quality & .504 & & & & & & \\
\hline Model at reduced price & & .815 & & & & & \\
\hline Product price & & .771 & & & & & \\
\hline Special offers & & .723 & & & & & \\
\hline Reliability & & .715 & & & & & \\
\hline Dual SIM option & & .702 & & & & & \\
\hline $\begin{array}{l}\text { Family members' } \\
\text { opinion }\end{array}$ & & .597 & & & & & \\
\hline Domestic product & & .588 & & & & & \\
\hline Charging hour & & & .751 & & & & \\
\hline $\begin{array}{l}\text { Complexity of } \\
\text { operating }\end{array}$ & & & .602 & & & & \\
\hline Battery & & & .459 & & & & \\
\hline $\begin{array}{l}\text { Key pad (Bengali or } \\
\text { English) }\end{array}$ & & & .455 & & & & \\
\hline Small size & & & & .872 & & & \\
\hline Weight & & & & .861 & & & \\
\hline $\begin{array}{l}\text { Friends' } \\
\text { recommendation }\end{array}$ & & & & & .799 & & \\
\hline $\begin{array}{l}\text { Colleagues' } \\
\text { recommendation }\end{array}$ & & & & & .536 & & \\
\hline $\begin{array}{l}\text { Neighbor } \\
\text { recommendation }\end{array}$ & & & & & & .729 & \\
\hline $\begin{array}{l}\text { Salespersons' } \\
\text { recommendation }\end{array}$ & & & & & & .496 & \\
\hline FM facilities & & & & & & .407 & \\
\hline Advertising & & & & & & & .763 \\
\hline
\end{tabular}

The above table indicates the number of factors those affect customers to choose mobile phone brands. From the rotation method the following seven factors (table 5) may be obtained. 
International Journal of Managing Value and Supply Chains (IJMVSC) Vol.5, No. 2, June 2014

Table 5- Naming of Factors

\begin{tabular}{|c|c|c|c|c|}
\hline $\begin{array}{l}\text { Factor } \\
\text { no. }\end{array}$ & $\begin{array}{l}\text { Name of } \\
\text { dimension }\end{array}$ & $\begin{array}{c}\text { Item } \\
\text { no }\end{array}$ & variables & $\begin{array}{l}\text { Factor } \\
\text { loading }\end{array}$ \\
\hline \multirow{13}{*}{ F1 } & \multirow{13}{*}{$\begin{array}{l}\text { Physical } \\
\text { attributes }\end{array}$} & 1 & Camera and video & .827 \\
\hline & & 2 & Bluetooth & .802 \\
\hline & & 3 & Multimedia option & .800 \\
\hline & & 4 & Touch screen & .775 \\
\hline & & 5 & Memory capacity & .772 \\
\hline & & 6 & Color display & .763 \\
\hline & & 7 & Attractive color & .753 \\
\hline & & 8 & Model/style & .684 \\
\hline & & 9 & New features & .684 \\
\hline & & 10 & Design of the phone & .669 \\
\hline & & 11 & Appearance & .608 \\
\hline & & 12 & Web browser & .597 \\
\hline & & 13 & Brand value/quality & .504 \\
\hline \multirow{7}{*}{ F2 } & \multirow{7}{*}{ Pricing } & 14 & Model at reduced price & .815 \\
\hline & & 15 & Product price & .771 \\
\hline & & 16 & Special offers & .723 \\
\hline & & 17 & Reliability & .715 \\
\hline & & 18 & Dual SIM option & .702 \\
\hline & & 19 & Family members' opinion & .597 \\
\hline & & 20 & Domestic product & .588 \\
\hline \multirow{4}{*}{$\mathbf{F 3}$} & \multirow{4}{*}{$\begin{array}{l}\text { Charging and } \\
\text { Operating } \\
\text { facilities }\end{array}$} & 21 & Charging hour & .751 \\
\hline & & 22 & Complexity of operating & .602 \\
\hline & & 23 & Battery & .459 \\
\hline & & 24 & Key pad (Bengali or English) & .455 \\
\hline
\end{tabular}

\begin{tabular}{|c|l|c|l|l|}
\hline \multirow{2}{*}{ F4 } & Size and weight & 25 & Small size & .872 \\
\cline { 3 - 5 } & & 26 & Weight & .861 \\
\hline \multirow{2}{*}{ F5 } & $\begin{array}{l}\text { Friends' and } \\
\text { colleagues' } \\
\end{array}$ & 27 & Friends' recommendation & .799 \\
\cline { 3 - 5 } & recommendations & 28 & Colleagues' recommendation & .536 \\
\hline \multirow{2}{*}{ F6 } & $\begin{array}{l}\text { Neighbors' } \\
\text { recommendations }\end{array}$ & 29 & Neighbor recommendation & .729 \\
\cline { 3 - 5 } & & 30 & Salesperson's recommendation & .496 \\
\hline \multirow{2}{*}{ F7 } & Advertising & 32 & FM facilities & .407 \\
\hline
\end{tabular}

\section{LIST OF FACTORS: Identified factors are listed below.}

6.1 Physical attributes: It is the most important factor. It can explain 30.99 percent of total variance in customer decisions of mobile purchasing. Physical attributes include all the physical characteristics of mobile phone like camera, Bluetooth, color, weight and others.

6.2 Pricing: It is the second factor which is capable to explain 10.49 percent of total variance. This second factor of pricing includes all the price related factors that the customers consider before buying 
mobile phones. It states that the Bangladeshi customers' psychology that influences buyer's decisions of purchasing mobile phone.

6.3 Charging and operating facilities: This is the third most important factor. It can explain 6.62 percent of total variance. Charging and operating facilities are taken into account while customers purchase mobile phones.

6.4 Size and weight: It is the fourth factor that explains 5.91 percent of total variance. There are many respondents who generally take the size and weight as important issues in buying mobile phone.

6.5 Friends' and colleagues' recommendations: This is the fifth factor which explains 4.40 percent of total variance. Some respondents take the suggestions from their friends and colleagues before purchasing mobile phones.

6.6 Neighbors' recommendations: It is the sixth factor which capable to explain 4.01 percent of total variance in customer decisions of mobile purchasing.

6.7 Advertising: The seventh factor explains 3.475 percent of total variance. It shows that customers also make their purchasing decision based on advertisement aired in various media.

\section{CONCLUSION}

The objective of the research was to find out the underlying factors those have a role to determine the brands while customers purchase mobile phone. It has been seen from the previous discussion that there are lots of variables customers consider before choosing brand of mobile phones. Some of the factors influence customers' decision greatly while others have comparatively low impact on the purchase decision. At the time of survey, it was observed that various types of facilities are expected by the customers. But this research work does not deal with the customer expectation. Rather it has tried to focus on the issues that the customers judge in the existing market scenario.

The research has identified that many factors are deemed as selection criteria of mobile phone. Not necessarily all the variables influence a person in the same way and same extent. In case of choosing mobile phone brands, mostly considered factors by customers include physical attributes, pricing, charging and operating facilities, size and weight, friends' and colleagues' recommendations, neighbors' recommendations and advertising.

\section{REFERENCES}

1. Batra, R and Ahtola, OT (1990). Measuring the hedonic and utilitarian sources of consumer attitudes, Marketing Letters, vol. 2, no. 2, pp. 159-170.

2. Chernev, A (2003). When more is less and less is more: The role of ideal point of availability and assortment in consumer choice', Journal of Consumer Research, vol. 30, no. 2, pp. 169-184.

3. Dorsch, MJ, Grove, SJ and Darden, WR (2000). Consumer intentions to use service category, Journal of Services Marketing, vol. 14, no. 2, pp. 92-118.

4. In-Stat/MDR (2002). The worldwide PDA market: the next generation of mobile computing, Research Report, Accessed 7 August.

5. Laroche, M, Kim, C and Matsui, T (2003). Which decision heuristics are used in consideration set formation, Journal of Consumer Marketing, vol. 20, no. 2, pp. 192-209. 
International Journal of Managing Value and Supply Chains (IJMVSC) Vol.5, No. 2, June 2014

6. Liu, CM (2002). The effects of promotional activities on brand decision in the cellular telephone industry, The Journal of Product \& Brand Management, vol. 11, no. 1, pp. 42-51.

7. Moorthy, S, Ratchford, B and Talukdar, D (1997). Consumer information search revisited, Journal of Consumer Research, vol. 23, no. 4, pp. 263-277.

8. Moschis, GP (1976). Social comparison and informal group influence, Journal of Marketing Research, vol. 13, pp. 237-244.

9. Requelme, H (2001). Do consumers know what they want?, Journal of Consumer Marketing, vol. 18 , no. 5, pp. 437-448.

10. Swait, J and Adamowicz, W (2001). The influence of task complexity on consumer choice: A latent class model of decision strategy switching, Journal of Consumer Research, vol. 28, no. 1, pp. 135-148.

11. Wilska, TA (2003). Mobile phone use as part of young people's consumption styles, Journal of Consumer Policy, vol. 26, no. 4, pp. 442-464. 